\title{
THE INFLUENCE OF LOCATION ON THE COMPETITIVENESS OF SOUTH AFRICAN INDUSTRIES
}

\author{
Ewert Kleynhans \\ North-West University, South Africa \\ Ewert.Kleynhans@nwu.ac.za \\ Ernst Drewes \\ North-West University, South Africa \\ Ernst.Drewes@nwu.ac.za
}

August 2008

\begin{abstract}
The effects of location on the international competitiveness of South African industries are investigated in this paper. The relationship between location and its competitiveness platform is important during the establishment of new manufacturing plants, as well as in the designing of industrial development policies by government and industry. This article studies the traditional factors that influence location first, followed by the modern factors, especially those emphasised by the so-called New Economic Geography. Then the empirical findings of a survey conducted among South African manufacturers regarding their location and its influence on their industrial competitiveness are reported.
\end{abstract}

Keywords:

Economic geography, competitiveness, spatial planning, industrial development, location, New Economic Geography (NEG), development economics. 


\section{INTRODUCTION}

In this article, the effects of location on the competitiveness of South African industries are investigated. The relationship between location and its competitiveness platform is important during the establishment of new manufacturing plants, as well as in the formulation of industrial development policies by government and industry. Locational decisions can determine profit margins, as well as the general competitiveness of firms. Transport and transaction costs are, for instance, much higher if markets or suppliers are located far from manufacturing plants, which could weaken market demand or jeopardise the production process.

Industries are regarded as engines of economic growth and employment opportunities, and this emphasises the significance of their location. Knowledge about the determinants of industrial location decisions is important to every town, as they all wish to attract industries to their regions and enjoy economic development. A thorough understanding of the dynamics and consequences of locational factors on the establishment of manufacturing industries is important for providing insights and understanding spatial development.

This article begins by discussing the traditional factors that influence location, before turning to modern factors, especially those emphasised by the so-called New Economic Geography. Then the empirical findings of a survey, which was conducted among South African manufacturers regarding their location and its influence on their industrial competitiveness, are reported.

\section{TRADITIONAL FACTORS OF INDUSTRIAL LOCATION}

The location of a manufacturing plant is selected on the basis of the interplay of various factors simultaneously. Maximum profit is, however, the first economic assumption. Survival in the economic world requires an optimal location where manufacturing and marketing efforts will result in the highest gains. The location will affect the costs at which raw material inputs are obtained, the costs of production, wage rates, the power of the trade unions, personal and product transport, costs of marketing, as well as the number of products demanded by the market. An optimal location, which will generate the highest possible profit margins, has to be found between resources and markets.

An important model for studying the traditional factors influencing location was presented by Alfred Weber (1929). He attempted to develop a reliable theory of industrial location. The basic idea of Weber's theory on the location of industries is that locational decisions in relation to a plant are made in order to minimise transportation costs or movement, implying the minimisation of distance, mass and effort (Weber, 1929:41). Weber (1929:37-38) also made three basic assumptions to simplify spatial development, namely that the physical position of raw materials is set; markets are set in terms of location and size; and there are only a fixed number of locations for manual labour. Weber suggested that there are regional and local factors influencing the location of industries (Smith, 1981:70). Regional factors include transport and labour costs, while local factors entail the forces of agglomeration or deglomeration. Using such a polygon of forces, an optimal point can be estimated where locational transport cost is at a minimum (Weber, 1929:49). Depending on the strength of the various forces, industries will locate somewhere between consumption and input factors, where the forces reach optimal equilibrium in the space economy. The least-transport-cost location 
will be, for example, the point at which the total number of ton-miles for the transportation of materials to a place of production and the final product to the marketplace is the lowest.

This highlights the importance of traditional factors in locational decisions and the optimisation of economic competitiveness enhancement. Friedmann (1966) and Porter (1998) noted a number of factors that play a role in the location and economic development of industries and regions. These include the transportation cost, the location of markets, the production process, the available technology, and the size of market demand. Other more recently identified factors include the economic environment, services and available infrastructure, regulations, the natural environment, and factors specific to the site, the corporate objectives and proximity to headquarters, uncertainty, as well as ambience and quality of life (see e.g. Wheeler, 1998).

Economic geography studies the location of economic activity across space, (Krugman, 1991a). During the last decade of the twentieth century, several papers were published on the so-called New Economic Geography, which also attempts to explain why industries cluster within particular countries and regions. The next section considers these factors.

\section{FACTORS OF THE NEW ECONOMIC GEOGRAPHY}

Alfred Marshall had stated the principles of the New Economic Geography as far back as 1890, but by the turn of the third millennium the effect of globalisation and modern technology once more made these principles relevant. This literature has some value as it enhances one's understanding of regional economic development and the established economic geographical theories. Isserman (1996:37) also says "...mainstream economists could not treat the messy problems of regional and development economics with formal mathematical models." Spatial economics can now benefit from the insights of the New Economic Geography literature. Economics today possesses the analytical, mathematical and econometric tools and "technical tricks" to handle spatial problems that were not possible in earlier days and it is now possible to shed more light on spatial science utilising the mathematical models of the new economics (Martin, 1999:75).

Spatial economic development is considered by New Economic Geography, focusing on production management, marketing and innovation as determinants of the spatial allocation of economic activity (Krugman, 1998:7; Isserman, 1996:37 \& Martin, 1999:75). Although oversimplified, the principles of the New Economic Geography for industrial location emphasise the importance of: a pool of skilled labour; supply of intermediate and non-traded inputs; and technological and knowledge spill-overs (Krugman, 1991c:484). Modern mathematical tools enable researchers to investigate the dynamics between these factors that determine modern geographical economic development.

According to Sunley (2003:188), "Marshall described the three classic types of localization economies: the formation of a pool of skilled workers, the nearby presence of supplying and supporting industries, and the local circulation of trade knowledge and secrets." These factors are also interrelated. Skilled workers are, for example, in a much better position to utilise spillovers. The dynamics of these factors provide advantages such as increasing returns at the level of the individual manufacturer (Arthur, 1996:102). Modern technology and engineering expertise enable firms to generate increasing returns to scale over a much larger section of the production function and lead to dynamic advantages that were not available in the past. Traditional 
theories are not compromised by modern research, but affirm it. They provide more insight into the role of manufacturing in the development of spatial economic geography, and may help to verify or refute stated hypothesises and support the spatial development of less-developed regions.

Modern analysis has the ability to test and confirm older economic theories empirically and in this way contribute to a better understanding of regional development. Van Rensburg (2000:3540) summarises its contribution as follows:
"New economic geography' is based on the argument that increasing returns, economies of scale and imperfect competition are more important than constant returns, perfect competition and comparative advantage in causing trade and specialisation. The market, technology and other externalities underpinning these increasing returns are not international or even national in scope, but arise through a process of regional or local economic agglomeration. The 'new economic geography' may be utilised in the main research programmes, namely an investigation into the spatial agglomeration of economic activity and an investigation into the dynamics of regional growth convergence (Martin, 1999: 67); the effects of differentiated physical geography on development (e.g. Gallup, Sachs \& Mellinger, 1998), and investigate the effects of geography on regional integration (e.g. Amjadi \& Winters, 1997)".

Modern Economic Geography abandoned constant returns and perfect competition. It gave new insight into economic spatial development and can also be utilised in less-developed regions. Various studies that indicate that profits increase when industries cluster together have recently been published by Porter (1998) and others (e.g. Arthur, 1996), supporting, for example, the New Economic Geography.

As the so-called standard Marshallian trilogy of skilled labour market pools, intermediate goods and knowledge spill-overs are rising in importance with regard to globalisation, New Economic Geography is becoming relevant. "By its very nature, globalisation is an economic geographical phenomenon, and traditional economic geographical ideas around spaces of flows, and places of control and production, are central to its understanding" (Barns \& Sheppard, 2003:3).

Modern technological development and engineering expertise in production, communication and competitive intelligence in this new economy present new challenges and opportunities to industries and regional development. As manufacturing becomes more productive with large pools of skilled labour, this may lead to the agglomeration of manufacturers at these growth nodes. When firms locate near each other, this provides agglomeration economics due to the spatial concentration of firms, making some regions more advantageous than others (Richardson, 1973:208). Changes in technology are rapid and sweeping (Warf, 2003:484) and countries without the ability to manage new developments "will remain beggars at the technological feast" (Grant, 2003:428). New technology utilises scientific and engineering capabilities, which require a higher degree of literacy and especially designing, computer and communication skills (Walker, 2003:505-509). Modern technology usually utilises skilled labour, while the demand for unskilled labour declines. This has specific implications for less-developed African regions, as modern technology puts firms in a position to attain increasing returns while those still employing traditional methods will price themselves out of the market. On the other hand, it would be detrimental to a region if modern technology leads to the application of capital-intensive technology and employment losses.

Knowledge is becoming the most important asset replacing manual work in the modern economy. 
As knowledge is shared and integrated in the production process, human capital is becoming the most important factor of production. A pool of skilled workers is becoming essential for a region to become and remain competitive. Furthermore, the value chain can now be sliced up in different ways and labour-intensive slices relocated in the production process (IDC, 2001:35), especially where specialisation and computers are utilised.

Many information-intensive activities and services previously classed as 'high value-added' activities are today 'real-time' activities that can be carried out anywhere in the global system (Unido, 2000:8). With the production of information goods, location does not matter, and this causes a new spatial organisation. Modern computers, knowledge, information goods and services, as well as orders of inputs can be outsourced and traded anywhere in the world. Increased global networking is central to global production. The international division of labour is changing, while firms can benefit and exploit linkages in the value system. The flow of trade, intermediate inputs, knowledge and technological spill-overs are increasing as liberalisation follows international agreements like the General Agreement on Tariffs and Trade (GATT) and the establishment of the World Trade Organisation. This increases cross-border trade between countries, while the application of modern technology accelerates development, especially through knowledge-based computer and communication technology (UNID0, 2000:10).

Manufacturers are undertaking new ways of production, conducting business and realising profits in the new economy. Mass production is being replaced by flexible production processes, which are able to react fast to changing market requests. They are also useful in cases where companies focus only on specific sections of the total production process of a commodity. This emphasises the need for intermediate inputs, which gradually change the spatial hierarchy. Flexible production emphasises the importance of clusters, industrial districts and networks (Helmsing, 2001:284). Related and supporting industries and institutions in the district provide the services or supply the intermediate input for production to firms, while others can take the production process to its conclusion (Helmsing, 1999:21). This has to be kept in mind when new surveys are being done among today's manufacturers.

In a growth pole or where clustering commences, industry-specific factors of production would more likely be found, including non-traded inputs (Krugman, 1991a:37). This generates industries that are more efficient, and reinforces development at that location. Where similar manufacturing companies cluster or utilise the same services, it will be profitable for supporting industries to obtain specialised and expensive machinery. Local markets may support efficient volumes of intermediate inputs. Specialised capital equipment that focuses on one small branch of a production process can pay for itself if it is utilised constantly by various manufacturers. A supply of these inputs in a region will make settling at that location more attractive to a new manufacturer.

External effects and spill-overs are important in the new economic geography. Literature on new economic geography suggests that areas where many manufacturers cluster together are usually more profitable sites and benefits outweigh the costs (Krugman, 1995:108 \& Porter, 1998:7). Pure externalities that result from knowledge spill-overs benefit all. When manufacturing agglomeration occurs, firms benefit from the information exchange that takes place (Krugman, 1991a:37). Jaffe, Trajtenberg and Henderson (1993) and Audretsch (1998:19) paid much attention to the effect of innovations, as well as technological and knowledge spill-overs. Krugman (1991a) acknowledges that information spill-overs are achieved when firms cluster together, putting them in a position to obtain higher production functions. The associated pecuniary externalities and demand or supply linkages also add benefits. Industrial clusters, 
districts or growth poles generate technological spill-overs due to the easier dissemination of information, leading to the faster development of new technological innovations. Processes, machinery and business organisation improve faster as there are more ideas and information available in an industrial centre.

Globalisation and modern technology emphasise the relevance of the New Economic Geography, since modern industrial development is severely limited without a pool of skilled labour, intermediate production factors and knowledge and technological spill-overs. These factors will influence industrial location and may improve economic efficiency, leading to increasing returns. The New Economic Geography also acknowledges other important locational factors, like historical factors (Krugman, 1991a:66-67) and the competition between centripetal forces (inward force, e.g. agglomeration), which promote geographical concentration, and centrifugal forces (force pushing away from the centre, e.g. pollution), which oppose concentration. Once development has occurred at a location, it is likely to persist for some time and will influence future events (Krugman, 1998:8).

The quality of human and physical resources, which are the important input factors of production, are dramatically influenced by both modern and traditional factors in the modern economy. Other important factors include services, business support and linkages, which can enhance trade and financing, as well as transport and transactional costs. The following section considers to what extent location of their manufacturing plants enhances the competitiveness of industries. It takes the form of a report on a survey that was conducted among South African manufacturers.

\section{EMPIRICAL SURVEY ON INDUSTRIAL LOCATION}

\subsection{The Industrial Competitive Platform Survey}

In order to evaluate the industrial competitiveness platform in South Africa a survey was conducted among manufacturing firms. This survey also provides insight into the influence of locational aspects on the competitiveness of manufacturers. A random sample of 450 manufacturing firms was drawn from the database of the Bureau of Market Research (UNISA) and questionnaires were disseminated during 2002. A response rate of 16.7 per cent was recorded, which is regarded as satisfactory for a mail-based survey in Africa. Although the authors preferred to report only on the results of firms that responded to the survey, as a case study, most findings correlate with earlier studies like those of the South African Netherlands Programme on Alternative Approaches to Development (SANPAD, 1999 \& 2000), as well as studies by Roberts and Mohamed (2005) and Walker and Phele (2005), and some generalisation might be in order.

Porter's Competitiveness Diamond was taken as the starting point in compiling the questionnaire, taking into consideration all aspects of the industrial competitive platform, like input factors of production, market conditions, 'firm strategy, structure and rivalry' and 'related and supporting firms' (Porter, 1998). The questionnaire was also extended to include aspects like location and expectations. Most questions of the questionnaire required respondents to rate their response on a five-point scale, ranging from "excellent" to "very bad". In the determination of various indices for manufacturing sub-sectors and provinces, the methodology applied was similar to the calculation of the World Competitive Indices by the International Institute for Management Development (IMD, 2008). 
Affirmative factor analysis was applied to the data and Cronbach-Alpha coefficients were determined. TABLE 1 shows some of the most important Cronbach-Alpha coefficients of the various groups of questions. In order to be reliable, Cronbach-Alpha coefficients should exceed 0.5 (Tabachnick, 2001:327). This table indicates that all the values were satisfactory, most exceeding 0.8 (Kleynhans, 2003a:242). The significantly high Cronbach-Alpha values indicate that the questionnaire was a reliable measuring instrument to evaluate the proposed objectives. The high Cronbach-Alpha values, and the consistency of the responses to the items in the survey, suggest that respondents completed the questionnaire with great care and a high degree of accuracy.

TABLE 1: Cronbach-Alpha Coefficients

\begin{tabular}{lc}
\hline \multicolumn{1}{c}{ Question Groups } & Coefficients \\
\hline Human Capital & 0.855 \\
Resources & 0.892 \\
Demand Conditions & 0.815 \\
Related \& Supporting Industries \& Institutions & 0.878 \\
Firm Strategy, Structure \& Rivalry & 0.873 \\
Technology \& Innovation & 0.914 \\
Quality \& Environment & 0.801 \\
Perspective \& Expectations & 0.868 \\
\hline
\end{tabular}

Source: Kleynhans, $2003 a$

The questionnaire was responded to by a good distribution of firms. More or less half of the respondents $(45,5 \%)$ represented small firms (employing less than 50 employees) and $28.8 \%$ were from large firms, employing more than 250 workers. The number of employees per firm ranged between one and 8400 employees. $47.6 \%$ of the responding firms had an annual turnover in excess of R10 million, $27 \%$ were between one and five million annually, and $15.9 \%$ had an annual turnover of less than one million rand.

The largest response (22.4\%) was from the sub-sector "manufacturing products of basic metals, machinery and office equipment". This was followed by $20.7 \%$ from "food processing and beverages", $12.1 \%$ by producers of "chemicals, chemical products, cokes, petroleum products, nuclear fuel, and products from rubber and plastic"; $21.1 \%$ represented "textiles, clothing and leather products", and $10.3 \%$ represented the sub-sectors of "electrical and electronic equipment" added together.

The spatial response from the nine provinces in South Africa was $39.6 \%$ from Gauteng, compared to 13.6 from the Eastern Cape, 12.1 from the North West Province and $10.6 \%$ from the Free State. The response from some provinces was too limited to enable generalisation. Information on subsector and provincial level should therefore only be seen as a case study and the calculation of competitive indexes as an academic exercise in which the instruments were developed for further research. Some firms were individually interviewed, making the response from Gauteng disproportionately high in comparison to the other provinces. Gauteng is, however, the most important centre of manufacturing, producing 33.3\% of South Africa's GDP (StatsSA, 2007:12). Findings concerning industrial location will now be discussed. 


\subsection{Factors that influence location}

The survey produced much detail, and most aspects of their location were rated as poor by the respondents. The worst factor was the availability of harbour facilities and the availability of ocean freight services. This might have been due to such a large proportion of respondents being situated in Gauteng and other inland provinces. Other locational aspects that stood out as most unsatisfactory included international airport facilities, the availability of cold storage facilities, the proximity of raw and semi-processed materials, and the availability of intermediate inputs and the lack in foreign investment. The role and efficiency of government was also recorded as most unsatisfactory. Government aid and incentives are regarded as failing, import tariffs and other international trade restrictions are most unsatisfactory as are political and policy stability. The strongest locational aspects concerning the premises of respondents are their proximity to main road links and the availability of main courier services. The reliability and quality of water supply and other utilities are regarded as excellent, although the costs of water, electricity, telecommunication services and other utilities are considered too high.

Traditional factors of location, as well as modern factors, are considered as poor with regard to the location of the various respondents. None of the traditional factors such as proximity of markets, low taxes, the availability of land, financial and trucking services, nor modern factors such as the proximity of support services, the availability of skilled labour and industrial training facilities are considered as enhancing efficiency and competitiveness due to their location.

\subsection{Linkages}

A total of $67.7 \%$ of the responding firms manufacture the complete product, while $37.3 \%$ indicated that they specialised in the manufacture of a part or phase of the final product. This implies that approximately one-third of the manufacturers are to some extent involved in and utilise other supporting industries and intermediate inputs in the industrial districts (Kleynhans \& Naude, 2006:396). They are, however, still far from true flexible production, which modern technology presents. Respondents also identified several potential industries that could settle in their vicinity, due to possible forward and backward linkages.

\subsection{The New Economic Geography}

The responding firms did not experience serious shortages of any kind, except with raw and intermediate materials and some levels of skilled labour that sometimes cause slight problems. All aspects of the new economic geography still fail competitiveness (Kleynhans, 2003:257). In most places, the pool of skilled labour is inadequate, intermediate inputs are sometimes difficult to find, non-tradable factors do not enhance competitiveness adequately and technological and knowledge spill-overs from other firms are poorly utilised. On the four corners of the Porter diamond of competitiveness (see Porter, 1998), input factors do not present serious obstacles. Demand conditions are poor, firm strategy, structure, rivalry and management are rated between fair and good, while support services and institutions are inadequately provided and not sufficiently utilised.

Based on the location of their plants, respondents rated the availability of skilled labour and training facilities on average as poor. The availability of sub-contractors, proximity to suppliers 
of spare parts and proximity of semi-processed material and/or intermediate inputs are regarded to be very poor. Proximity of professional and support services is poor and the availability of other manufacturing industries in the industrial districts and business support services is also rated as poor. Respondents rate none of the main factors identified as important as fair, good or superior in relation to the location of their sites.

Human capital in South African manufacturing industries is rated as poor. The availability of artisans, technically skilled labour and managerial staff is insufficient and vocational and industry-related training facilities are inadequate (Kleynhans, 2006:58). Management skills and practices are, however, seen as being significantly better than the other levels of labour and most aspects in this regard are rated as reasonable.

To some extent, flexible production is present with regard to linkages between firms and the usage of intermediate inputs. Critical activities are shared, indicating co-operation in the value chain and sub-contracting with other manufacturers highlights the importance of related industries in the industrial districts and clusters. Government policies like Spatial Development Initiatives (SDIs) and Industrial Development Zones (IDZs) have little effect on manufacturers achieving increasing returns and economies of scale.

Sufficient investment in new technology is taking place; specialisation in the production of specific components and phases of the production process is growing, while firms are becoming increasingly dependent on related industries and services in the industrial district or virtual districts in their computer network of contacts. Support services, business associations and social infrastructure, and the scope available in industrial districts and networks, are becoming more valuable. Manufacturers do, however, still experience problems with the proximity of semiprocessed materials and the availability of intermediate inputs. Elements typical of flexible production, such as various linkages and sub-contracting, the continuous upgrading of input and production processes, and shorter production runs are increasing, indicating that manufacturers are gradually moving towards modern manufacturing practices, which could eventually make them internationally competitive and able to compete in the new global economy.

Respondents rated their business contacts and the support from trade and business associations as having a fair influence on their competitiveness in the industrial districts. Business and supporting industries and institutions do have some positive influence on the competitiveness of manufacturers. Maintenance and support services do not hamper activities and manufacturers do not foresee that they would in the near future. The utilisation of technological and knowledge spill-overs is seen as being poor, decreasing the advantages of agglomeration in industrial districts. Although some linkages, including linkages to technology and information, exist and flexible production does occur, economies of scope in most industrial districts are not yet satisfactorily developed, constraining the advantages that agglomeration has to offer. The availability of technology and knowledge support services is not hampering activities and manufacturers do not foresee that it would in the near future. The telecommunication services in South Africa are predominantly rated between fair and good, together with the provision of electricity, water and other utilities, and superior to most other supporting services (Kleynhans, 2006:376), (this view might change due to increasing loadshedding). The road and rail network is regarded as fair, but air and sea transport and traffic at border posts and harbours are seen as poor and not conducive to the competitiveness of industries.

With regard to transport costs, the road and rail network does not present major obstacles to the 
competitiveness of firms, while air and sea transport and traffic at the border and harbour posts do. As most of the manufacturers are landlocked, the availability of harbour facilities is a problem pushing up costs, but with a well-developed road network in South Africa, this is not always a serious problem. A large cost factor to respondents is the costs and availability associated with trucking services, as is the proximity to national airports.

\subsection{Spatial Development Initiatives}

During 1995, the South African government initiated the Spatial Development Initiative (SDI) programme in an attempt to improve government functioning within those regions with the greatest potential for economic growth of the country. Currently, eleven local SDIs are in varying stages of development. These include the Maputo Development Corridor; Lubombo SDI; Richards Bay SDI, including the Durban and Pietermaritzburg nodes; Wild Coast SDI; Fish River SDI; West Coast Investment Initiative; Platinum SDI; Phalaborwa SDI and the Coast-2-Coast Corridor.

SDls are targeted by central government to help unlock economic potential and facilitate new investment and job creation in a localised area or region (Jourdan, 1998:718). The SDI programme allows for a six-year tax-holiday, three-year depreciation allowance and foreign location cash grant for potential investors within an identified SDI (Jourdan, 1998:717). The SDI programmes provide infrastructure and information, alleviate investment and financing constraints, improve co-operation with government and identify strategic investment opportunities through research (Jourdan, 1998:718). The objective is to strengthen the performance of key sectors in the local economy - most often tourism and industrial sectors.

Most manufacturers in the survey were unaware of SDI programmes, although most firms are situated in or near SDIs. Only $12.3 \%$ of the respondents indicated that they are situated in or near an SDI. This confirms the suspicion that provincial governments are not committed to the development of SDIs and that leadership is lacking in this regard (see Kleynhans, Naude \& Van der Merwe, 2003:617). $89.7 \%$ of the respondents believed that the introduction of SDIs or development corridors did not enhance manufacturing in their firms in any way. Only 6.3 per cent found that the introduction of SDIs or development corridors led to increasing returns and/or economies of scale in their companies. Poor communication from government and its agencies is evident and thus improvement in its administration and service, better communication and well-planned information and campaigns from government to inform the public and improve the image of government are warranted.

\section{LOCATIONAL ASPECTS ACCORDING TO FIRMS' SIZE}

As with most other factors of competition, the quality of the location of their premises rises with firm size. The study revealed a great deal of detailed information. Large firms consider the quality and availability of water as the most important advantage of their locations, followed by the reliability of the electrical supply, and the availability of courier, trucking, corporate finance and health services. The poorest locational aspects are the lack of cold storage, proximity of semi-processed materials and the proximity, costs and quality of international airport facilities. As with all other firms, one of the biggest obstacles to competitiveness regarding location is the low quality, efficiency and availability of government incentives, aid, support, tariffs, international trade restrictions and the inefficiency of the civil service. Business support services and investments from abroad are also poor. 
Locational aspects enhance the competitiveness of medium-sized firms most and the strongest factors, rated between good and excellent, were their proximity to main road links, and the availability of courier and financial services. Other factors rated as good were the reliability of the water and electrical supply and their personal contact with customers. As most respondents were from landlocked provinces, all regarded the availability of harbour facilities and ocean freight services as poor, and medium firms regarded it as totally inadequate. As could be expected, there was a large standard deviation on this question as most companies do not export and some are near the sea. Firms also have problems with cold storage, the quality and support from the public authorities and insufficient investment from abroad. Other factors rated as poor by the respondents from medium-sized firms were the availability and proximity of raw and semi-processed materials and intermediate inputs, business support services and other manufacturing firms in the industrial districts. This indicates a lack of the most important locational aspects emphasised by the new economic geography.

The strongest locational aspects of small firms are their proximity to main road links and the reliability and quality of telecommunication, water, electricity and other utilities. Other aspects that were rated as most satisfactory were the availability of trucking and courier services. Firms find labour costs to be a fair obstacle - to small firms this is a little bit more severe - but the differences between firms of different sizes are not significant. Small firms perceive investment from abroad, import tariffs and other international trade restrictions as weak aspects of their location and competitiveness. Next to their frustration with government support and services, the poorest factors related to location are the distance from airports, the unavailability of industrial land, proximity to suppliers of spare parts and availability of intermediate inputs. In general, all respondents regard the government and civil service as uncooperative and incompetent. The next section discusses the effect that location of their premises has on the international industrial competitiveness platform of provinces.

\section{COMPETITIVENESS OF PROVINCES}

The study of the industrial competitive platform of provinces revealed that KwaZulu-Natal, the North West Province and Mpumalanga are the most competitive provinces. Location affects firms in the various provinces in different ways, but those stated above occur in all. Firms in Gauteng, the North West Province, Mpumalanga and the Western Cape are most satisfied with the location of their premises and all plan to expand their operations within the next three years.

Transport costs are a problem, especially in the Eastern Cape, while KwaZulu-Natal enjoys a positive advantage in this regard. The quality of and proximity to main road links and railheads enhance the competitiveness of most responding firms, except those in Limpopo. Respondents were requested to rate the locational aspects of their premises. TABLE 2 summarises the strongest factors (S) that enhance their international competitiveness most, as well as the worst aspects $(W)$. It is only indicated where constructs are significantly strong or weak. According to TABLE 2, most aspects relating to transport, such as costs, quality and proximity to airports and harbours, are enhancing the competitiveness of industries in KwaZulu-Natal. These aspects are, however, obstacles in the other provinces, especially the North West Province, Mpumalanga, the Eastern and Northern Cape and the Free State. Ocean freight also severely influences competitiveness in the Northern and Eastern Cape provinces. The availability of trucking and container services enhances competitiveness in the North West Province, the Eastern Cape and Free State, but is retarding it in the Western Cape and Mpumalanga. 
TABLE 2: عffect of Location on Competitiveness: Transport Issues

\begin{tabular}{|c|c|c|c|c|c|c|c|c|c|}
\hline $\begin{array}{c}\text { Strengths }=S \\
\text { Weaknesses }=W\end{array}$ & 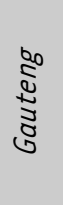 & 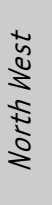 & $\begin{array}{l}0 \\
0 \\
5 \\
0 \\
0 \\
5 \\
5 \\
\frac{2}{2}\end{array}$ & 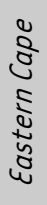 & 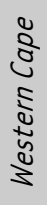 & 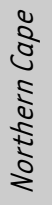 & 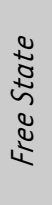 & 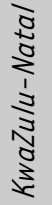 & $\begin{array}{l}8 \\
8 \\
8 \\
8 \\
\vdots \\
\vdots\end{array}$ \\
\hline $\begin{array}{l}\text { Quality and proximity to } \\
\text { main road links }\end{array}$ & S & & $S$ & $S$ & & & $S$ & $S$ & S \\
\hline $\begin{array}{l}\text { Quality and proximity to } \\
\text { railheads }\end{array}$ & & & & & & & S & & W \\
\hline $\begin{array}{l}\text { Quality and proximity to } \\
\text { airports }\end{array}$ & & & & & & W & W & S & W \\
\hline Airline facilities & & W & & W & & W & W & S & W \\
\hline Harbour facilities & & W & W & W & & W & W & S & \\
\hline Ocean services & & & & W & & W & & & \\
\hline $\begin{array}{l}\text { Availability of container } \\
\text { services }\end{array}$ & & S & W & S & W & W & S & & \\
\hline Courier services & $S$ & & S & $S$ & & $S$ & & & $S$ \\
\hline Trucking services & & & & W & & & $S$ & & \\
\hline Container services & & S & W & $S$ & W & & S & & \\
\hline Cold storage facilities & & W & & W & W & & W & W & W \\
\hline Transport cost & & & & W & & & & $S$ & \\
\hline
\end{tabular}

Source: Author

The availability of cold storage restricts competitiveness in all provinces. Eastern Cape firms perceive personal contact with customers as a strength, while Free State firms view their distance from markets as a negative factor. Distance from harbour facilities is usually a problem to landlocked provinces.

With regard to the input factors of production, a scarcity of raw materials is not a severe problem in South Africa, although the Northern Cape experiences problems in this regard, probably due to its remote location. Semi-processed intermediate inputs and spares are an obstacle in Mpumalanga, the Eastern and Northern Cape, but they also enhance productivity in the Free State and KwaZulu-Natal. There is an abundance of industrial land in Limpopo, but the cost of land is a problem everywhere, especially in KwaZulu-Natal. Housing for employees and key personnel enhances competitiveness in Limpopo, the Free State and Western Cape, but is an obstacle in the North West Province. High rates and taxes also retard competitiveness, and their effect is worst in the Western Cape and KwaZulu-Natal.

Respondents perceive the quality of communication, electricity, water and other utilities as extremely positive, but their cost is, however, restricting competitiveness in the Free State and Northern Cape. Only Limpopo has problems with water supply, but Limpopo is also the only province that reaps competitive benefits due to the low price of water and utilities.

Although Gauteng is the largest contributor to South Africa's GDP, it is not the most competitive. In Gauteng $36.8 \%$ of manufacturers specialise in the production of only some part or phase of 
the final production. Co-operation within the industrial districts of Gauteng, the Northern Cape and KwaZulu-Natal is low due to the absence of firms and the low level of industrial development. The same applies to the support from business support services, especially in the Northern Cape. The North West Province is the only province where it is supportive. Technological and knowledge spill-overs are rarely utilised, especially in Gauteng, while they provide a competitive advantage in the Free State.

The absence of aid and incentives from government is an obstacle to all respondents. Respondents also experience international tariffs and other trade restrictions as leading to competitive disadvantages, especially in the North West Province, Mpumalanga, the Free State, and the Northern, Eastern and Western Cape. However, criticism of government is not fair, as the authorities are bound by the GATT agreements. Investment from abroad enhances the competitiveness of North West firms, but is still not efficient, especially in Mpumalanga, the Eastern Cape, Free State and KwaZulu-Natal. High investment risk was perceived by respondents to be the worst in the Free State. On the other hand, corporate financial services are well developed in South Africa, and are influencing output extremely positively in the Eastern Cape and KwaZulu-Natal. Respondents rate environmental legislation as unclear and costly, severely retarding competitiveness in Limpopo and the Free State.

TABLE 3: عffect of Location on Competitiveness: Human Capital

\begin{tabular}{|c|c|c|c|c|c|c|c|c|c|}
\hline & G & NW & MP & $\varepsilon \subset$ & WC & NC & $\mathrm{F}$ & KZ & $\mathrm{L}$ \\
\hline Skilled labour & & $S$ & & & & & & $S$ & \\
\hline Semi- and unskilled labour & S & & & & S & & & & \\
\hline Industrial training facilities & & & W & & & & & & W \\
\hline Professional services & & & & & & & & s & \\
\hline
\end{tabular}

Source: Author

Although most locations, especially the Northern Cape, experience problems with the utilisation of sub-contractors and proximity to support services, the Free State is so well positioned that these aspects contribute to their competitiveness. Professional services are a positive factor for KwaZulu-Natal, but not elsewhere. Semi-skilled and unskilled labour is abundant in Southern Africa and is especially to the advantage of Gauteng and the Western Cape. Skilled labour is, however, a problem. TABLE 3 indicates that the North West Province and KwaZulu-Natal enjoy positive gains due to skilled labour in their areas, but all provinces need more vocational and industry-related training facilities, especially Limpopo and Mpumalanga.

\section{COMPETITIVENESS OF MANUFACTURING SUB-SECTORS}

When the ten major manufacturing sub-sectors (food and beverages, textile and clothes, paper and wood products, chemicals, fuel and petroleum, non-metal, metal products, electrical machines, electronic equipment, transport equipment and furniture) were studied, it was found that the competitiveness of the different sub-sectors is more or less equal. Food processing and transport equipment manufacturers seem to be the most competitive, but the others are not 
much worse. An alarming aspect was the low level of technological proficiency, expertise and innovation in the science- and technology-based industries like chemicals and electronics. If South Africa is to survive in the new economy, its level of technological expertise, capabilities and capacity will have to be considerably improved.

In most industries, the cost and reliability of telecommunication services, water and electricity are the strongest factors related to location, together with good main road links and courier services. Personal contact with customers, the availability of corporate financial services, and semi-skilled and unskilled labour are also rated as good. The biggest problems reducing competitiveness are a shortage of container and trucking services, intermediate inputs and aid and incentives from government, which are all regarded as failing. Other locational factors rated as poor by respondents are ocean freight, harbour and airline facilities, high transport costs, distance of railheads and markets, import tariffs, as well as other international trade restrictions and a shortage of raw materials.

Respondents rated transport and its cost as the strongest aspects relating to the location of their premises. The quality and proximity of main road links are the most positive aspects. Proximity of railheads is an obstacle to non-metallic mineral products, electronics and furniture, while it enhances competitiveness of the transport equipment industry. Harbour facilities and ocean freight severely hampers the competitiveness of most sectors, while the availability and proximity of airlines and harbour facilities also cause problems. The food and beverages sub-sector also experiences a shortage of cold storage facilities. With regard to trucking services, respondents were divided. The quality and availability thereof enhance competitiveness of food processing, basic metals, transport equipment and furniture sectors, while chemicals and electronics experience these services as an obstacle.

Considering the extent to which location influences trade and financial issues, international tariffs and trade restrictions cause problems. Personal contact with customers enhances competitiveness, as well as distance from markets; however, textiles, paper and electronics consider it a problem. Except for chemicals, most sectors succeed in utilising financial services to their advantage, and only furniture rates investment risk as an obstacle. Investment from abroad is not adequate, especially in the food, beverages and furniture sectors.

TABLE 4: Effect of Location on Competitiveness: Human Capital

\begin{tabular}{|c|c|c|c|c|c|c|c|c|c|c|}
\hline & $F d$ & $T x$ & $\mathrm{~Pa}$ & Ch & N.m & Mt & $\varepsilon / m$ & $\varepsilon / c$ & $\operatorname{Tr}$ & $F u$ \\
\hline Skilled labour & & & W & & & & $S$ & & W & $\mathrm{S}$ \\
\hline Semi- and unskilled labour & S & & & S & & S & S & & & $\mathrm{S}$ \\
\hline Industrial training facilities & & & & & & & W & & W & W \\
\hline Professional services & & W & & W & & & W & & W & \\
\hline
\end{tabular}

Source: Author

TABLE 4 indicates the effect of location on the quality of human capital. Availability is a huge problem, especially in the textiles, chemicals, electrical machinery and transport equipment sub-sectors. Most sectors experience problems with the availability of skilled labour, especially paper and transport equipment, while this aspect enhances the competitiveness of the electrical 
machinery and furniture sub-sectors. Semi-skilled and unskilled labour is in abundance everywhere, but the absence of vocational and industrial training facilities causes problems, especially in the electrical machinery, transport equipment and furniture sub-sectors.

When considering the effect of location on production input factors, the quality and reliability of communication, electricity, water and other utilities enhance the competitiveness of all sectors, but their cost causes problems, especially to textiles and transport equipment. The cost and availability of industrial land only cause severe problems for chemicals and non-metallic mineral products, while the paper and electrical machinery sectors regard the availability of land as a positive aspect. Food, electrical machinery, transport equipment and furniture are considering expansion within the next three years, and at the same premises. Although no respondents regard the availability of raw materials and semi-processed intermediate goods and spares as a serious problem, nearly all sectors rated it as a negative aspect retarding competitiveness. Only furniture, mostly situated near forests, regards raw material inputs as an enhancing aspect and is even considering expansion there.

The effect of location on competitiveness due to services, business support, and knowledge and technological spill-over linkages is mostly negative. Sub-contractors are well utilised, especially in the textiles, chemicals and non-metallic mineral industries. These linkages are, however, limited in most sectors and this has a severely negative impact on electronics. Distance and availability of support services fail most industries, especially textiles and electronics, while this is a point of strength to the transport equipment sector. All respondents feel that the government fails them with regard to aid and incentives. After-sales service is excellent in the electronics sub-sector, but most sectors experience problems in this regard, especially chemicals and transport equipment. Business support services are enhancing production locally, except in the food industries, and international contact is limited.

\section{SUMMARY}

This article considered the relationship between location and the international competitiveness of manufacturing firms. Firstly, attention was paid to the traditional factors that influence locational decisions in the setting up of new manufacturing plants, as well as theories that model such spatial development. Thereafter, more modern factors and theories were considered, especially those found in the so-called New Economic Geography. The second half of the article reported on the findings of a survey that was conducted among manufacturing industries to assess their competitiveness platform in South Africa. This article focused primarily on the relation between the location of manufacturing plants and how this affected their efficiency and competitiveness.

Traditional factors will always remain important factors for locational decisions and enhancing competitiveness. These factors include aspects like infrastructure, services, the economic environment, the natural environment, factors specific to the site, corporate objectives and proximity to headquarters, uncertainty, ambience and quality of life. Many contracts are, for example, entered into on golf courses instead of in boardrooms.

The effects of modern technology and globalisation, as well as international agreements on tariffs and import quotas, are growing in importance in the modern economy. These principles were considered by Marshall as far back as 1890 , but by the turn of the third millennium they are once again significant factors. New Economic Geography provides more insight into the role of 
manufacturing and the development of spatial economic geography. Modern technology and production are dependent on a pool of skilled workers, intermediate factors of production and knowledge and technological spill-overs as the world is transforming from an industrial era to the information age. Traditional factors of production, like market demand and the availability of resources, remain important aspects influencing decisions on location; however, modern research does not contradict traditional theories and economic geography, but affirms it.

The last part of the article reported on aspects affecting location, which were revealed in a survey conducted among manufacturing firms in South Africa. To determine spatial differences due to the location of manufacturing plants, special attention was paid to factors influencing location, linkages, new economic geography, flexible production, as well as spatial aspects influencing firms in various provinces, of various sizes and the sub-sectors of manufacturing.

It was found that strengths and weaknesses among most firms are quite similar. Firms do not experience serious shortages of any kind except with raw and intermediate materials and some levels of skilled labour that sometimes cause slight problems. In relation to the New Economic Geography, all aspects still fail to be competitive. In most places the pool of skilled labour is inadequate, intermediate inputs are sometimes difficult to find, non-tradable factors do not enhance competitiveness adequately and technological and knowledge spill-overs from other firms are poorly utilised.

The availability of skilled labour and training facilities are on average rated as poor by respondents. The proximity of professional and support services is poor and the availability of other manufacturing industries and business support services in the industrial districts is also rated as poor. The availability of sub-contractors, proximity to suppliers of spare parts and the proximity of semi-processed material and/or intermediate inputs are regarded as very poor.

The survey has shown that the country does possess better levels of human capital, technology and quality than is usually assumed, but it still lacks most factors that would attract new industries to settle in the region. Government policies can have a stultifying influence on industrial location and development, and modern policies should enhance the competitiveness of industries in the new economy, ensuring that people receive the necessary skills and the country obtains the capabilities and technology that are needed.

\section{FURTHER RESEARCH}

Competitive indices for provinces were estimated in this study and indices for the various components, like technology, resources and management - and these findings correlated well with productivity indices. The same applies to sub-sectors of manufacturing and different firm sizes; but as the response rate was too small to differentiate the sample into such small units, it can at this stage only be regarded as an academic exercise. The instruments were, however, developed in this study and can now be implemented in further investigations. Further research, especially with larger samples, can enable the comparison of firms in the various sub-sectors of manufacturing, like food processing, basic metal products and textiles, as well as the various provinces, and also suggests an agenda for development. A more mathematical approach can also be followed in the determination of the correlation between location and competitiveness, in relation to traditional models, like those of Weber (1929), as well as modern factors, such as the studies by Fujita, Krugman and Venables (2001).

In order to confirm results, to determine whether structural changes have occurred and to 
rectify changing perceptions, this study should ideally be conducted annually and on a larger scale. Perceptions of the manufacturer with regard to utilities, especially for example electricity, have probably already changed due to shortages and load-shedding. More reliable data may be generated and obtained on a regular basis if annual surveys are conducted. This can provide policymakers, industries and researchers with instruments to design and enhance industrial development programmes and policies, especially in a spatial context. Some findings of this study also contradicted other studies and conventional wisdom, and this should be verified. The fact that land-locked provinces, for example, do not have a competitive disadvantage in comparison with coastal provinces should be questioned. Regular surveys would enable generalisation of the findings and determine whether trends persist over time. However, much more funding to enable additional research and follow up will be required.

\section{REFERENCES}

Arthur, W. B. (1996). Increasing returns and the new world of business, Harvard Business Review, 74(4), pp. 100-109.

Audretsch, D. B. (1998). Agglomeration and the Location of Innovative Activity, Oxford Review of Economic Policy, 14(2), pp. 18-29.

Friedmann, J. (1966). Regional Development Policy: A case study of Venezuela. Massachusetts: M.I.T. Press.

Fujita, M., Krugman, P. \& Venables, A. J. (2001). The spatial economy. Cities, regions and international trade. Cambridge: M.I.T. Press.

Hägerstrand, T. (1965). Aspects of the spatial structure of social communication and the diffusion of information, Regional Science Association: Papers, 16, pp. 27-42.

Helmsing, A. H. J. (1999). Flexible specialisation, clusters and industrial districts and 'second' and 'third generations' regional policies. Institute of Social Studies, The Hague. (Working paper series no. 305).

Helmsing, A. H. J. (2001). Externalities, learning and governance perspectives on local economic development. Development and Change, 32(2), pp. 277-308.

IDC. (2001). Industrial development framework. Analytical document. Federal Democratic Republic of Ethiopia. Prepared by IDC for Unido and Ministry of Planning and Economic Development. Sandton: Industrial Development Corporation.

IMD. (2008). World competitiveness yearbook. Lausanne: International Institute for Management Development.

Isserman. A. M. (1996). It's obvious, it's wrong, and anyway they said it years ago? Paul Krugman on large cities, International Regional Science Review, 19(1), pp. 37-48.

Jaffe, A. B., Trajtenberg, M. \& Henderson, R. (1993). Geographic Localization of Knowledge Spillovers as Evidenced by Patent Citations, Quarterly Journal of Economics, 108(3), pp. 577-598.

Jourdan, P. (1998). Spatial Development Initiatives (SDIs) - the Official View, Development Southern Africa, 15(5), pp. 717-725.

Kleynhans, દ. P. J. (2003a). The competitive platform for industrial development in South Africa. Unpublished PhD thesis. Potchefstroom: Potchefstroom University. 
Kleynhans, E. P. J. (2003b). The effect of globalisation on industrial development: The South African Experience. Paper delivered at the Conference on Clusters, Industrial Districts and Firms: University of Modena and Reggio Emelia, Modena, Italy, 12 September.

Kleynhans, E. P. J. (2006). The role of human capital in the competitive platform of South African industries, SA Journal of Human Resource Management, 4(3), pp. 55-62.

Kleynhans, દ. P. J. \& Naudé, W. A. (2006). Suid-Afrikaanse nywerheidsontwikkeling te midde van globalisasie en moderne tegnologie, Tydskrif vir Geesteswetenskappe, 46(3), pp. 367-380.

Kleynhans, દ. P.J., Naudé, W. A. \& Van der Merwe, S. J. (2003). Spatial Economic Development in South Africa: An Overview and Evaluation of the Platinum Spatial Development Initiative, Development Southern Africa, 20(5), pp. 617-631.

Krugman, P. (1991a). Geography and Trade. Cambridge: M.I.T.

Krugman, P. (1991b). Increasing Returns and Economic Geography, Journal of Political Economy, 99(3), pp. 483-499.

Krugman, P. (1995). Development, Geography, and Economic Theory. Cambridge: M.I.T.

Krugman, P. (1998). What's New about the New Economic Geography? Oxford Review of Economic Policy, 14(2), pp 7-17.

Marshall, A. (1890). Principles of Economics. London: Macmillan.

Martin, R. (1999). The new 'geographical turn' in economics: some critical reflection, Cambridge Journal of Economics, 23(1), pp. 65-91.

Porter, M. દ. (1998). The Competitive Advantage of Nations; with a New Introduction. New York: Palgrave.

Richardson, H. W. (1973). Regiona/ Growth Theory. New York: John Wiley.

Roberts, S. \& Mohamed, L. (2005). Analysis of the Technological Challenge Faced by the Plastics Sector and its Dynamism. Paper delivered at a workshop on The Role of Networks, Relationships, Industrial Clusters and Innovation Systems in Africa: Johannesburg, 10 March 2005.

Smith, D.M. (1981). Industrial Location: An Economic Geographical Analysis. London: John Wiley.

South Africa. Department of Housing. (2001). Housing Atlas. Intentions of the Housing At/as (20012002). Available from:

http://www.housing.gov.za/content/housing_atlas/housing_atlas.htm\#national_programme_ alignment. (Accessed 25 October 2007)

South Africa Netherlands Research Programme on Alternatives in Development (SANPAD). (1999). First Annual Report 1999: Manufacturing Survey: North West Province of South Africa. Prepared by Naudé, W. A., Oostendorp, R., Anand, V. K. \&. Serumaga-Zake, P. Potchefstroom: Potchefstroom University.

South Africa Netherlands Research Programme on Alternatives in Development (SANPAD). (2000). Annual Report 2000: The Manufacturing Sector in North West Province. Prepared by Naudé, W. A., Serumaga-Zake, P. \& Oostendorp, R. Potchefstroom: Potchefstroom University.

StatsSa. (2007). Gross Domestic Product. Statistical release P044l, Statistics South Africa, 27 November 2007. Pretoria: Statistics South Africa.

Sunley, P. (2003). Urban and Regional Growth. In:Sheppard, દ. \& Barnes, T.J. (eds.) A Companion to Economic Geography. Oxford: Blackwell. (pp. 189-201) 
Tabachnick, B.G. (2001). Using Multivariate Statistics. Boston: Allyn \& Bacon.

UNIDO. (2000). Industry and Trade in a Global Economy- With Special Reference to Sub-Saharan Africa. Vienna: UNIDO. Aug. 2001.

Van Rensburg, L. (2000). Role of Transport Costs and Logistics in South Africa's International Competitiveness. Unpublished M.Com dissertation. Potchefstroom: Potchefstroom University for Christian Higher Education.

Walker, M. \& Phele, T. (2005). Understanding the Dynamics of a Mining Cluster. Paper delivered at a workshop on The Role of Networks, Relationships, Industrial Clusters and Innovation Systems in Africa: Johannesburg, 10 March 2005.

Walker, R.A. (2003). The Geography of Production. In:Sheppard, \&. \& Barnes, T.J. (eds.) A Companion to Economic Geography. Oxford: Blackwell. (pp. 113-132)

Warf, B. (2003). Telecommunications and economic space. In:Sheppard, \&. \& Barnes, T.J. (eds.) A Companion to Economic Geography. Oxford: Blackwell. (pp. 484-498)

Weber, A. [translated by Carl J. Friedrich from Weber's 1909 book] (1929). Theory of the Location of Industries. Chicago: The University of Chicago Press.

Wheeler, J. 0., Muller, P. O., Thrall, G. I. \& Fick, T. J. (1998). Economic Geography, $3^{\text {t }}$ edition. New York: John Wiley and Sons, Inc. 
Kleynhans \& Drewes 